\title{
KORELASI ANTARA KEMAMPUAN BAHASA ARAB DENGAN PEMAHAMAN AYAT-AYAT AL-QUR'AN TERHADAP SISWA KELAS XII MADRSAHALIYAH AL-AMANAH KOTA BAUBAU
}

\author{
Ahmad Karim \\ Achmad Abubakar \\ Amrah Kasim \\ achmad.abubakar@uin-alauddin.ac.id
}

\begin{abstract}
Abstrak: Penelitian ini membahas tentang tingkat kemampuan bahasa Arab dan tingkat pemahaman ayat-ayat al-Qur'an serta korelasi antara keduanya terhadap siswa kelas XII Madrasah Aliyah (MA) Al-Amanah Baubau. Penelitian ini adalah penelitian lapangan (field reseach) bersifat kuantitatif dalam bentuk ex-post facto atau kasual komparatif karena penelitian ini berusaha mencari informasi tentang hubungan sebab akibat dari suatu peristiwa. Data dikumpulkan melalui tes (soal) dari hasil jawaban Ujian Akhir Madrasah Berstandar Nasional (UAMBN). Hasil penelitian dan pembahasan: (1) Setiap siswa memiliki kemampuan yang berbedabeda dalam menjawab tes soal bahasa Arab dan al-Qur'an pada Ujian Akhir Madrasah Berstandar Nasional. Tingkat pemahaman siswa kelas XII MA Al-Amanah Baubau dapat menerima/menyerap pelajaran al-Qur'an dengan sangat positif dan signifikan; (2) Korelasi antara tingkat kemampuan bahasa Arab dengan tingkat pemahaman ayat-ayat al-Qur'an dipengaruhi oleh kemampuan bahasa Arab siswa kelas XII MA Al-Amanah Baubau. Penelitian ini dapat memberi sumbangsih pemikiran dan pengetahuan bagi siswa dan guru agar lebih giat menguasai dan memahami pembelajaran bahasa Arab dan al-Qur'an, menjadi referensi atau rujukan yang relevan bagi kaum akademisi, lembaga pendidikan atau institusi penelitian lainnya dalam melakukan kajian dan penelitian yang terkait dengan tingkat kemampuan bahasa Arab dan tingkat pemahaman ayat-ayat al-Qur'an di MA Al-Amanah Baubau.
\end{abstract}

Keywords: Kemampuan; Pemahaman; Bahasa Arab; Ayat-ayat AlQur'an

\section{PENDAHULUAN}

Pendidikan pada dasarnya merupakan upaya untuk mengarahkan anak didik ke dalam proses belajar sehingga menjadi yang terbaik sesuai dengan potensi yang mereka miliki. Menurut Zakiyah Darajat, pendidikan agama Islam adalah suatu usaha untuk membina dan mengasuh peserta didik agar senantiasa 
dapat memahami kandungan ajaran Islam secara menyeluruh, menghayati makna tujuan, yang akhirnya dapat mengamalkan serta menjadikan Islam sebagai pandangan hidup. ${ }^{1}$ Mengingat pentingnya pendidikan Islam, oleh karena itu, ketika menyebut pendidikan Islam maka akan mencakup dua hal, (a) mendidik siswa untuk berperilaku sesuai dengan nilai atau akhlak Islam; (b) mendidik siswa untuk mempelajari materi ajaran Islam subyek berupa pengetahuan tentang ajaran Islam.

Mata pelajaran pendidikan agama Islam itu secara keseluruhannya terhimpun dalam lingkup al-Qur'an dan hadis, aqidah akhlak, fikih/ibadah, sejarah kebudayaan Islam, dan bahasa Arab, sekaligus menggambarkan bahwa ruang lingkup pendidikan Agama Islam mencakup perwujudan keselarasan, dan keseimbangan hubungan manusia dengan Allah swt, diri sendiri, sesama manusia, makhluk lainnya, maupun lingkungannya. ${ }^{2}$ Bahasa Arab merupakan salah satu bahasa asing yang banyak dipelajari masyarakat Indonesia, khususnya di madrasah dan pesantren. MA Al-Amanah Baubau menyelenggarakan pembelajaran pendidikan agama Islam untuk menyiapkan siswa memiliki kemampuan membaca, mempelajari, menerjemahkan al-Quran secara umum dengan baik dan benar, memiliki keterampilan keagamaan, dan berakhlak mulia serta menguasai keterampilan bahasa Arab dengan baik dan benar.

Sebagaimana fenomena yang terjadi di MA Al-Amanah Baubau. Penggunaan bahasa Arab sangat ditekankan dalam proses belajar mengajar baik didalam ataupun diluar ruang kelas. Asumsi yang berkembang bahwa semua pembelajaran agama Islam disampaikan dengan bahasa Arab oleh guru dan ditanggapi oleh siswa dengan bahasa Arab pula. Tradisi seperti inilah yang menjadikan kemahiran dalam bahasa Arab penting demi memahami tiap proses belajar mengajar di madrasah yang lebih efektif dan efisien. Selain itu, siswa bisa menerima kegiatan kebahasaan di asrama. Karena siswa berada dalam lingkungan yang sama selama 24 jam dan menjadikan asrama sebagai pusat kegiatan para siswa MA Al-Amanah Baubau. Dengan adanya penelitian ini, diharapkan kemampuan bahasa Arab dan pemahaman ayat-ayat al-Qur'an siswa MA AlAmanah Baubau bertambah dan meningkat, serta dapat mengamalkannya dalam kehidupan sehari-hari.

Pokok masalah dalam penelitian ini adalah "Bagaimana Korelasi antara Kemampuan Bahasa Arab dengan Pemahaman Ayat-Ayat Al-Qur'an Terhadap Siswa Kelas XII MA Al-Amanah Baubau". Adapun batasan masalah dalam penelitian ini:

\footnotetext{
${ }^{1}$ Zakiyah Darajat, Pendidikan Islam dalam Keluarga dan Sekolah (Jakarta: YPI Ruhama, 1996), h. 35.

${ }^{2}$ Abdul Majid, Belajar dan Pendidikan Agama Islam, (Bandung: PT. Remaja Rosdakarya, 2014), h. 11-13.
} 
1. Bagaimana tingkat kemampuan bahasa Arab dan tingkat pemahaman ayatayat al-Qur'an siswa kelas XII MA Al-Amanah Baubau?

2. Bagaimana korelasi antara tingkat kemampuan bahasa Arab dan tingkat pemahaman ayat-ayat al-Qur'an siswa kelas XII MA Al-Amanah Baubau?

\section{B. Definisi Operasional dan Ruang Lingkup Penelitian}

1. Kemampuan bahasa Arab

Kemampuan bahasa Arab dalam penelitian ini adalah kesanggupan, atau kecakapan siswa kelas XII MA Al-Amanah Baubau memiliki kemahiran mendengar, berbicara, membaca, dan menulis untuk menyampaikan apa yang terlintas di dalam hatinya, baik berupa ide, pikiran dan gagasan kepada orang lain dengan menggunakan bahasa Arab untuk merespon baik secara lisan maupun tulisan.

2. Pemahaman ayat-ayat al-Qur'an

Pemahaman ayat-ayat al-Qur'an adalah kesanggupan, kecakapan dan kemampuan menerjemahkan, menafsirkan dan memahami secara tekstual ayat-ayat al-Qur'an dan dapat diamalkan dalam kehidupan sehari-hari.

Ruang lingkup penelitian terdiri dari tingkat kemampuan bahasa Arab dan tingkat pemahaman ayat-ayat al-Qur' an siswa kelas XII MA Al-Amanah Baubau, serta korelasi antara tingkat kemampuan bahasa Arab dan tingkat pemahaman ayat-ayat al-Qur'an siswa kelas XII MA Al-Amanah Baubau.

\section{TINJAUAN TEORETIS}

\section{A. Kemampuan Bahasa Arab}

Hoetomo mengatakan bahasa adalah sistem lambang bunyi yang arbitrer, yang dipergunakan oleh para anggota suatu masyarakat untuk bekerjasama, berinteraksi, dan mengidentifikasikan diri; percakapan (perkataan) yang baik, tingkah laku yang baik; sopan santun. ${ }^{3}$ Sementara kata "Arab" Secara etimologi dapat berarti nama bangsa di jazirah Arab dan Timur Tengah; atau nama bahasa bangsa Arab. ${ }^{4}$ Para ahli dalam mengemukakan pengertian bahasa Arab sangat beragam, di antaranya:

Jurji Zaidah mengatakan;

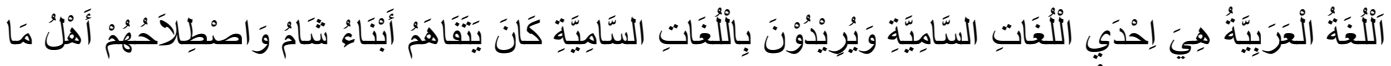

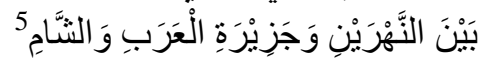

Maksudnya:

${ }^{3}$ Hoetomo, Kamus Lengkap Bahasa Indonesia (Surabaya: Mitra Pelajar, 2005), h.75.

${ }^{4}$ Hoetomo, Kamus Lengkap Bahasa Indonesia, h. 57.

${ }^{5}$ Jurji Zaidah, Tārīkhu Adab al-Lugāti al- 'Arabiyyah, (Jakarta: Dār al-Hilāl, t.th.), h. 35. 
Bahasa Arab adalah salah satu bahasa Smith, yang mereka maksud bahasa Smith adalah bahasa yang dipakai anak cucu Syam dan menurut istilah mereka yaitu bahasa penduduk yang berada di antara dua sungai dan jazirah Arab dan negara Syam.

Bahasa Arab adalah salah satu bahasa di jazirah Arab dan Timur Tengah, yang termasuk dalam rumpun bahasa Semit dan berkerabat dengan bahasa Ibrani dan bahasa-bahasa Neo Arami.

Kemampuan dalam Kamus Umum Bahasa Indonesia berasal dari kata "mampu" yang berarti kuasa (sanggup melakukan sesuatu), berada; kaya. Kemampuan berarti kesanggupan; kecakapan; kekuatan; kekayaan. ${ }^{6}$

Wood Woorth dan Marquis mengatakan, sebagaimana dikutip oleh Sumadi Suryabrata, kata kemampuan mempunyai tiga pengertian yaitu: ${ }^{7}$

1. Achievement yang merupakan actual ability yang dapat diukur secara tidak langsung dengan alat tes.

2. Capacity yang merupakan potensial ability yang dapat diukur secara tidak langsung dengan melalui pengukuran terhadap kecakapan individu, dimana kecakapan itu berkembang melalui training yang intensif dan pengalaman.

3. Attitude, yaitu kualitas yang hanya dapat diungkap atau diukur dengan tes khusus yang sengaja dibuat untuk itu.

Robbins mengatakan ada dua faktor yang mempengaruhi kemampuan:

1. Kemampuan intelektual (intellectual ability) merupakan kemampuan yang diperlukan untuk mengerjakan kegiatan mental.

2. Kemampuan fisik (physical ability) merupakan kemampuan yang diperlukan untuk melakukan tugas-tugas yang menuntut stamina, kecekatan, kekuatan, dan keterampilan serupa. ${ }^{8}$

Tujuan utama pembelajaran bahasa Asing adalah pengembangan kemampuan siswa dalam menggunakan bahasa baik lisan maupun tulis. Bahasa Arab merupakan suatu disiplin ilmu yang terdiri dari berbagai aspek keterampilan. Utama yaitu: 1) Mendengar (Mahārah al-Istimā'), 2) Berbicara (Mahārah alKalām), 3) Membaca (Mahārat al-Qirāah), 4) Menulis (Mahārah al-Kitābah). ${ }^{9}$

Siswa yang belajar bahasa Arab akan mudah menguasai bahasa Arab apabila ia memulainya dengan melatih keterampilan-keterampilan tersebut secara berurutan yang dimulai dari keterampilan mendengar, berbicara, membaca, dan menulis. Demikian juga, ia akan mengalami kesulitan untuk memiliki kemampuan

${ }^{6}$ W.S.J. Poerwadarminta, Kamus Umum Bahasa Indonesia diolah kembali oleh Pusat Bahasa, Edisi III (Cet. IV; Jakarta: Balai Pustaka, 2011), h. 742.

${ }^{7}$ Sumadi Suryabrata, Psikologi Pendidikan (Jakarta: Rajawali, 1986), h. 169.

${ }^{8}$ Universitas Petra, Pengertian Kemampuan (ability). http://digilib.petra.ac.id (Akses 10 Juli 2018).

${ }^{9}$ Muhammad Alî al-Khūlī, Asalīb Tadrīs al-Lughah al- 'Arabīyah (Beirut: Dar al-Fikr, tt), h. $19-20$. 
bahasa Arab yang baik apabila ia mempelajarinya dengan tidak mengindahkan sistematika keterampilan yang harus dikuasainya. ${ }^{10}$ Proses pembelajaran bahasa Arab secara sistematika dimulai dari mendengar, berbicara, membaca, dan menulis akan memudahkan penguasaan bahasa Arab. Demikian pula sebaliknya, kesulitan bagi siswa yang tidak paham sistematika keterampilan yang harus dikuasainya.

Pembelajaran bahasa Arab di kalangan masyarakat non Arab, memiliki kendala dan problematika yang biasanya muncul:

1. Problematika linguistik

Problematika linguistik adalah kesulitan-kesulitan yang dihadapi siswa dalam proses pembelajaran yang diakibatkan oleh karakteristik bahasa Arab itu sendiri sebagai bahasa asing bagi anak-anak Indonesia. Adapun yang termasuk problematika linguistik yaitu tata bunyi, kosa kata, tata kalimat dan tulisan. ${ }^{11}$ Problem ini acap kali dialami oleh siswa terutama bagi siswa pemula yang belum sama sekali mengenal bahasa Arab dengan baik.

2. Problematika non linguistik

Di samping persoalan linguistik yang dihadapi oleh siswa non Arab, juga persoalan non linguistik menjadi kendala keberhasilan pembelajaran. Problematika non linguistik muncul di luar zat bahasa itu sendiri, di antaranya:

a. Faktor sosio-kultural, problem yang mungkin muncul ialah bahwa ungkapanungkapan, istilah-istilah dan nama-nama benda yang tidak terdapat dalam bahasa Indonesia tidak mudah dan tidak cepat dipahami oleh siswa Indonesia yang sama sekali belum mengenal sosial dan budaya bangsa Arab.

b. Faktor buku ajar, faktor penggunaan buku ajar dalam pembelajaran juga menjadi sesuatu yang urgen. Buku ajar yang tidak memperhatikan prinsipprinsip penyajian materi bahasa Arab sebagai bahasa asing akan menjadi problem tersendiri dalam pencapaian tujuan.

c. Faktor lingkungan sosial, belajar bahasa yang efektif adalah membawa siswa ke dalam lingkungan bahasa yang dipelajari. Dengan lingkungan tersebut setiap siswa akan dipaksa untuk menggunakan bahasa tersebut, sehingga perkembangan penguasaan bahasa yang dipelajarinya relatif lebih cepat dibandingkan dengan mereka yang tidak ada di lingkungan bahasa tersebut. Hal ini karena lingkungan akan membuatnya terbiasa menggunakan suatu bahasa secara terus-menerus untuk menyampaikan maksud. ${ }^{12}$

${ }^{10}$ Abu Bakar Muhammad, Ilmu Nahwu Teori Mudah Untuk Mempelajari Bahasa Arab (Surabaya: Karya Abditama, 1996), h. 1-3.

${ }^{11}$ Acep Hermawan, Metodologi Pembelajaran Bahasa Arab, (Cet. IV; Bandung: PT Remaja Rosdakarya, 2014), h. 100.

${ }^{12}$ Acep Hermawan, Metodologi Pembelajaran Bahasa Arab, (Cet. IV; Bandung: PT Remaja Rosdakarya, 2014), h. 105-109. 
Dua komponen problematika penguasaan bahasa arab tersebut, menjadi domain pembelajaran bagi siswa untuk lebih aktif dan giat menambah pengetahuan penguasaan bahasa Arab, baik dari segi kosa kata, pelafalannya, maupun dari susunan kalimat dan kaidahnya.

\section{B. Pemahaman Ayat-Ayat al-Qur'an}

Pemahaman merupakan upaya untuk memahami suatu masalah dengan menggunakan metode tertentu. Pemahaman juga didefinisikan sebagai langkah untuk mendalami suatu materi dengan cara mencermati secara detail sehingga mengerti makna apa yang sedang dipelajari. ${ }^{13}$

Daryanto mengatakan pemahaman berdasarkan tingkat kepekaan dan derajat penyerapan materi dapat dijabarkan, yaitu: ${ }^{14}$

1. Menerjemahkan (Translation)

Pengertian menerjemahkan bisa diartikan sebagai pengalihan arti dari bahasa yang satu ke dalam bahasa yang lain. Dapat juga dari konsepsi abstrak menjadi suatu model simbolik untuk mempermudah orang mempelajarinya. Contohnya dalam menerjemahkan BhinekaTunggal Ika menjadi berbeda-beda tapi tetap satu.

2. Menafsirkan (Interpretation)

Kemampuan ini lebih luas daripada menerjemahkan, ini adalah kemampuan untuk mengenal dan memahami, dilakukan dengan cara menghubungkan pengetahuan yang lalu dengan pengetahuan yang diperoleh berikutnya.

3. Mengekstrapolasi (Extrapolation)

Ekstrapolasi menuntut kemampuan intelektual yang lebih tinggi karena seseorang dituntut untuk bisa melihat sesuatu dibalik yang tertulis, meramal tentang konsekuensi atau memperluas persepsi dalam arti waktu, dimensi, kasus, ataupun masalahnya.

Tingkatan pemahaman mengisyaratkan bahwa bagi seorang siswa mudah menguasai materi yang diajarkan, bila memiliki kepekaan terhadap materi. Sehingga proses pembelajaran dapat berlangsung dengan baik, sesuai dengan tingkatan pemahaman yang dimiliki oleh siswa.

Ayat berarti beberapa kalimat yang merupakan kesatuan maksud sebagian dari bab dalam kitab suci atau al-Qur'an (biasanya dinyatakan dengan angka): قر أيقر أ- قرء-وقراءةyang memiliki makna mengumpulkan, menghimpun dan membaca. Disebut

\footnotetext{
${ }^{13}$ Poerwadarminto, Kamus Besar Bahasa Indonesia (Jakarta: Balai Pustaka, 1998), h. 528.

${ }^{14}$ Zuchdidan Darmiyati, Strategi Meningkatkan Kemampuan Membaca (Yogyakarta: UNY Press, 2007), h. 24.

${ }^{15}$ W.J.S. Poerwadarminto, Kamus Umum Bahasa Indonesia, h. 72.
} 
demikian karena al-Qur'an menghimpun beberapa surah. ${ }^{16}$ Sebagaimana firman Allah swt dalam QS al-Qiyāmah/75:17-18.

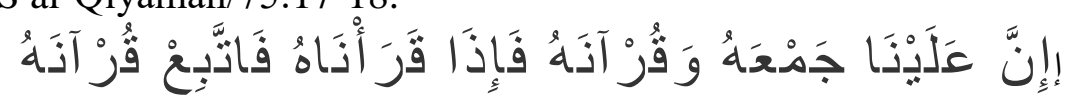

Terjemahnya:

Sesungguhnya Kami yang mengumpulkannya (di dadamu) dan membacakannya. Apabila Kami telah selesai membacakannya maka ikutilah bacaannya itu. ${ }^{17}$

Mannā' al-Qațtān mengatakan al-Qur'an adalah kitab yang diturunkan kepada Nabi Muhammad saw. yang membacanya menjadi suatu ibadah. ${ }^{18}$ Ahli bahasa Arab, ahli fikih dan ushul fikih menyatakan bahwa al-Qur'an teks (lafal) yang diturunkan kepada Nabi Muhammad saw. mulai dari surah al-Fātiḥah sampai al-Nās. Prof Nasharuddin Baidan menyimpulkan bahwa al-Qur'an adalah kalam Allah yang kita jumpai saat ini dalam mushaf Us\}mani mulai dari al-Fātiḥah sampai al-Nās, bukan kalam yang masih berada pada Tuhan, dan bukan pula yang berada di Laūh al-Mahfüz. ${ }^{19}$

Faktor-faktor yang mempengaruhi pemahaman antara lain:

1. Faktor Interen

Faktor intern Yaitu faktor intelegensi, orang berpikir mengunakan inteleknya.

2. Faktor Eksteren

Faktor ekstern yaitu berupa faktor dari orang yang menyampaikan, karena penyampaian akan berpengaruh pada pemahaman

Adapun faktor-faktor yang mempengaruhi pemahaman sekaligus keberhasilan belajar siswa ditinjau dari segi kemampuan pendidikan adalah sebagai berikut:

1. Tujuan

Tujuan adalah pedoman sekaligus sebagai sarana yang akan dicapai dalam kegiatan belajar mengajar. Perumusan tujuan akan mempengaruhi kegiatan pengajaran yang dilakukan oleh guru sekaligus mempengaruhi kegiatan belajar siswa. Dalam hal ini tujuan yang dimaksud adalah pembuatan. Tujuan Intruksional Khusus (TIK) oleh guru yang berpedoman pada Tujuan Intruksional Umum (TIU). Penulisan Tujuan Intruksional Khusus (TIK) ini dinilai sangat penting dalam proses belajar mengajar, dengan alasan:

\footnotetext{
${ }^{16}$ Muhammad bin Mukram bin Manẓūr al-Afrìīi al-Mișrī, Lisān al- 'Arab (Cet. I; Beirut: Dār Șādir, t.th.), h. 128.

${ }^{17}$ Kementerian Agama RI, Mushaf al-Qur'an dan Terjemah (Jakarta: Ummul Qura, 2017), h. 577.

${ }^{18}$ Syeikh Mannā' al-Qațtān, Mabāhï̉ fì 'Ulūm al-Qur'ān (Cet. XIII; Kairo: Maktabah Wahbah, 2004), h. 18.

${ }^{19}$ Nasharuddin Baidan, Metode Penafsiran al-Qur'an (Cet. I; Yogyakarta: Pustaka Siswa Offset, 2002), h. 30.
} 
a. Membatasi tugas dan menghilangkan kekaburan dan kesulitan di dalam pembelajaran.

b. Menjamin dilaksanakannya proses pengukuran dan penilaian yang tepat dalam menetapkan kualitas dan efektifitas pengalaman belajar siswa.

c. Dapat membantu guru dalam menentukan strategi yang optimal untuk keberhasilan belajar. ${ }^{20}$ Berdasarkan uraian tersebut, maka yang dimaksud dengan tujuan adalah perbuatan guru dalam pembelajaran berpengaruh terhadap kegiatan siswa.

2. Guru

Guru adalah tenaga pendidikan yang memberikan sejumlah ilmu pengetahuan pada siswa di madrasah. Guru adalah orang yang berpengalaman dalam bidang profesinya. Didalam satu kelas, siswa satu berbeda dengan lainnya. Untuk itu setiap individu berbeda tingkat keberhasilan belajarnya.

3. Siswa

Siswa adalah pembelajar yang dengan sengaja datang ke madrasah untuk belajar bersama guru dan teman sebayanya. Mereka memiliki latar belakang yang berbeda, bakat, minat dan potensi yang berbeda pula. Sehingga dalam satu kelas pasti terdiri dari siswa yang bervariasi karakteristik dan kepribadiannya.

Hal ini berakibat pada berbeda pula cara penyerapan materi atas tingkat pemahaman setiap siswa. Dengan demikian dapat diketahui bahwa siswa adalah unsur manusiawi yang mempengaruhi kegiatan belajar mengajar sekaligus hasil belajar atas pemahaman siswa.

4. Kegiatan Pengajaran

Kegiatan Pengajaran adalah proses terjadinya informasi antara guru dengan siswa dalam kegiatan belajar mengajar. Kegiatan pengajaran ini merujuk pada proses pembelajaran yang diciptakan guru dan sangat dipengaruhi oleh bagaimana keterampilan guru dalam mengolah kelas.

Komponen-komponen tersebut meliputi: pemilihan strategi pembelajaran, penggunaan media dan sumber belajar, pengajaran guru, sarana prasarana pendukung. Kesemuanya itu akan sangat membentuk kualitas belajar siswa. Dimana hal-hal tersebut jika dipilih dan digunakan secara tepat, maka akan menciptakan suasana belajar yang pembelajaran aktif, kreatif, efektif, menyenangkan, dan inovatif (PAKEMI).

5. Suasana evaluasi

Keadaan kelas yang tenang, aman dan disiplin juga berpengaruh terhadap tingkat pemahaman siswa pada materi (soal) ujian yang sedang mereka kerjakan. Hal itu terkait denga konsentrasi dan kenyamanan siswa. Mempengaruhi bagaimana siswa memahami soal berarti pula mempengaruhi jawaban yang

${ }^{20}$ Ivor K. Davies dan Sudarsono Sudirdjo, Pengelolaan Belajar (Jakarta: CV. Rajawali Press, 1991), h. 96. 
diberikan siswa. Jika hasil belajar siswa tinggi, maka tingkat keberhasilan proses belajar mengajar akan tinggi pula.

\section{Bahan dan alat evaluasi}

Bahan dan alat evaluasi adalah salah satu komponen yang terdapat dalam kurikulum yang digunakan untuk mengukur pemahaman siswa. Alat evaluasi memiliki cara-cara dalam menyajikan bahan evaluasi, misalnya dengan memberikan butir soal bentuk benar salah (true-false), pilihan ganda (multiple choice), menjodohkan (matching), melengkapi (completation), dan essay. Dalam penggunaannya, guru tidak harus memilih satu alat evaluasi tetapi bisa menggunakan lebih dari satu alat evaluasi.

Penguasaan secara penuh (pemahaman) siswa tergantung pada bahan evaluasi atau soal yang diberikan guru kepada siswa. Jika siswa telah mampu mengerjakan atau bahan evaluasi dengan baik, maka siswa dapat dikatakan paham terhadap materi yang diberikan.

Setelah diketahui faktor-faktor apa saja yang mempengaruhi pemahaman maka diketahui pula kalau pemahaman dapat dirubah. Pemahaman sebagai salah satu kemampuan manusia yang bersifat fleksibel, sehingga pasti ada cara untuk meningkatkannya.

Berikut adalah langkah-langkah yang dapat digunakan dalam upaya meningkatan pemahaman siswa:

a. Memperbaiki proses pengajaran

Langkah ini merupakan langkah awal dalam meningkatkan proses pemahaman siswa dalam belajar. Proses pengajaran tersebut meliputi: memperbaiki tujuan pembelajaran, bahan (materi), pembelajaran strategi, metode, dan media yang tepat serta pengadaan evaluasi belajar. Yang mana evaluasi ini bertujuan untuk mengetahui seberapa besar tingkat pemahaman siswa terhadap materi yang diberikan. Tes ini bisa berupa tes formatif, tes submatif dan sumatif. ${ }^{21}$

Uraian tersebut memberi gambaran tentang pemahaman manusia yang bersifat fleksibel, sehingga untuk meningkatkan proses pemahaman siswa dalam belajar dibutuhkan perbaikan-perbaikan berupa tujuan pembelajaran, bahan (materi), pembelajaran strategi, metode, dan media yang tepat serta pengadaan evaluasi belajar.

b. Adanya kegiatan bimbingan belajar

Kegiatan bimbingan belajar merupakan bantuan yang diberikan kepada individu tertentu agar mencapai taraf perkembangan dan kebahagiaan secara optimal. Adapun tujuan dari kegiatan bimbingan belajar adalah:

1) Mencarikan cara-cara belajar yang efektif dan efisien bagi siswa.

\footnotetext{
${ }^{21}$ Syaiful Bahri Djamarah dan Aswan Zaini, Strategi Belajar Mengajar (Jakarta: PT. Rineka Cipta, 1996), h. 129.
} 
2) Menunjukkan cara-cara mempelajari dan menggunakan buku pelajaran.

3) Memberikan informasi dan memilih bidang studi sesuai dengan bakat, minat, kecerdasan, cita-cita dan kondisi fisik atau kesehatannya.

4) Membuat tugas madrasah dan mempersiapkan diri dalam ulangan atau ujian.

5) Menunjukkan cara-cara mengatasi kesulitan belajar. ${ }^{22}$

Salah satu tugas guru adalah memberikan bantuan pelayanan kepada siswa melalui bimbingan belajar untuk mencapai taraf perkembangan dan kebahagiaan secara optimal dengan tujuan mencarikan cara belajar yang efektif dan efisien bagi siswa, menunjukkan cara mempelajari dan menggunakan buku pelajaran, memberikan informasi dan memilih bidang studi sesuai dengan bakat, minat, kecerdasan, cita-cita dan kondisi fisik atau kesehatan siswa, membuat tugas sekolah dan mempersiapkan diri dalam ulangan atau ujian dan menunjukkan caracara mengatasi kesulitan belajar siswa.

\section{Hubungan antara Tingkat Kemampuan Bahasa Arab dan Tingkat Pemahaman Ayat-Ayat al-Qur'an}

Penguasaan siswa terhadap bahasa Arab sangat berpengaruh terhadap penahaman ayat-ayat al-Qur'an, sebab apabila siswa itu mampu menguasai bahasa Arab dengan baik mulai dari nahwu, sharof dan kosa kata, maka akan lebih mudah dalam memahami ayat-ayat al-Qur'an. Sedangkan apabila siswa kurang menguasai bahasa Arab, akan berpengaruh terhadap pemahaman siswa dalam memahami ayat-ayat al-Qur'an bahkan akan merasa kesulitan. Sebagaimana yang disampaikan Ali Al-Najjar dalam Syahin yang dikutip oleh Azhar Arsyad mengungkapkan: "Bahasa Arab merupakan bahasa yang terluas dan terkaya kandungannya". ${ }^{23}$ Atas dasar itulah, maka orang yang hendak memahami hukumhukum (ajaran) agama Islam dengan baik haruslah berusaha mempelajari bahasa Arab.

\section{Kerangka Pikir}

Untuk lebih jelasnya arah gambaran penelitian ini, dapat dilihat dari kerangka pikir berikut ini:

\footnotetext{
${ }^{22}$ Abu Ahmadi dan Widodo Supriyono, Psikologi Belajar (Jakarta: Rineka Cipta, 2004), h. 105 .

${ }^{23}$ Azhar Arsyad, Bahasa Arab dan Metode Pengajarannya: Beberapa Pokok Pikiran (Yogyakarta: Pustaka Pelajar, 2003), h. 6-7.
} 


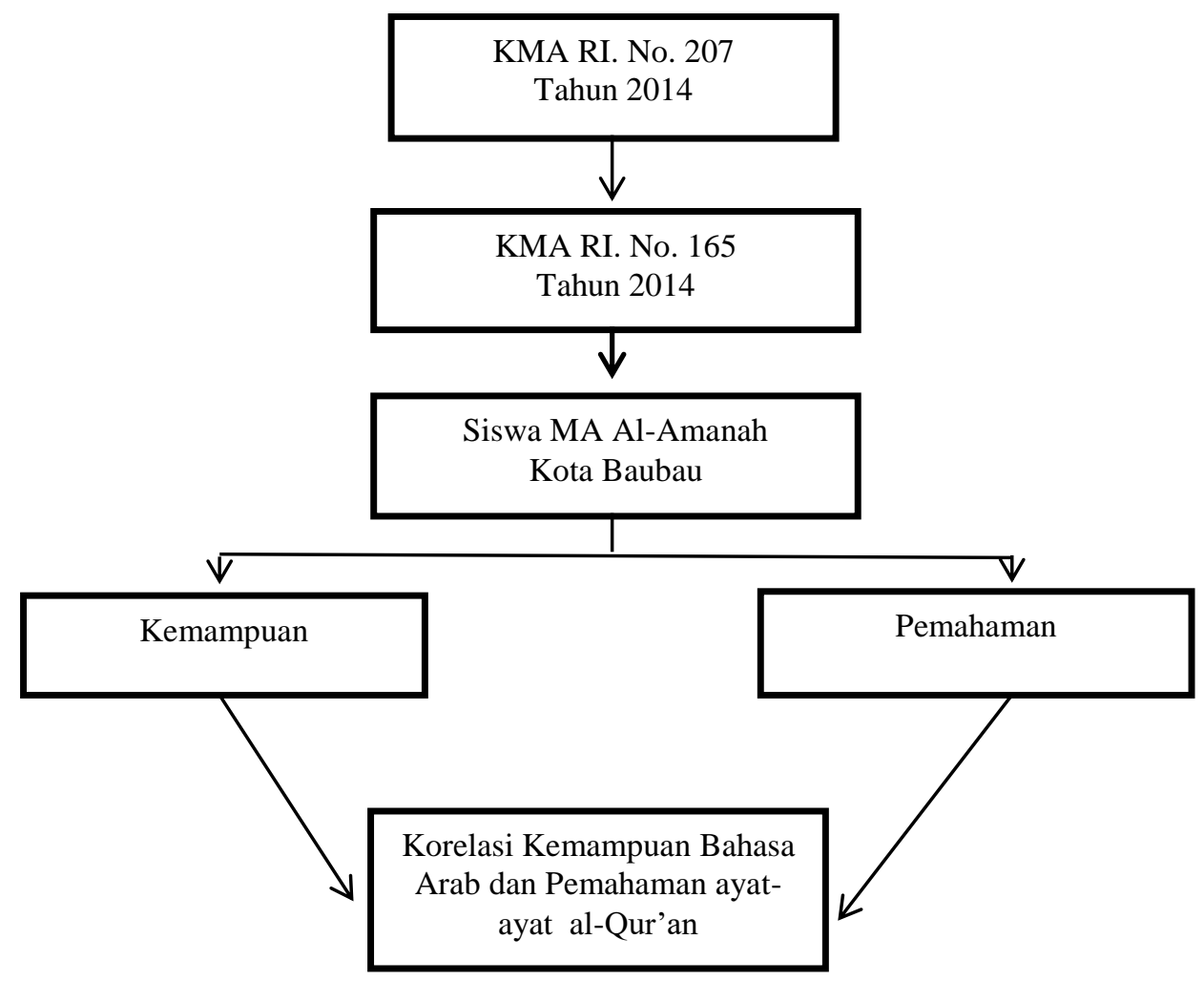

\section{III.METODOLOGI PENELITIAN}

Penelitian ini adalah penelitian lapangan (Field Research) bersifat kuantitatif, ${ }^{24}$ dalam bentuk ex-post facto. Istilah ex-post facto menunjukkan bahwa penelitian yang dilakukan untuk meneliti peristiwa yang telah terjadi dan peneliti dihadapkan kepada masalah bagaimana menetapkan sebab dari akibat yang sedang diamati, kemudian meruntut ke belakang untuk mengetahui faktor-faktor yang dapat menimbulkan kejadian tersebut. Penelitian ini disajikan dalam bentuk deskriptif berdasarkan variabel penelitian, pengumpulan data untuk menentukan apakah ada korelasi antara dua variabel atau lebih. Sedangkan untuk mencari hubungan maupun prediksi, digunakan hipotesis sebagai petunjuk dalam pemecahan masalah penelitian. Variabel dalam penelitian ini terdiri dari:

a. Independent variable atau variable bebas (X).

Variabel bebas dalam penelitian ini adalah tingkat kemampuan bahasa Arab. Indikatornya adalah hasil jawaban soal bahasa Arab Ujian Akhir Madrasah Berstandar Nasional (UAMBN) siswa kelas XII MA Al-Amanah Baubau.

b. Dependent variabel atau variable terikat (Y)

Variabel terikat dalam penelitian ini adalah tingkat pemahaman ayat-ayat al-Qur'an. Indikatornya adalah hasil jawaban soal al-Qur'an UAMBN siswa kelas XII MA Al-Amanah Baubau.

\footnotetext{
${ }^{24}$ Sugiyono, Metode Penelitian Pendidikan (Bandung: Alfabeta, 2007), h. 14.
} 
Penelitian ini dilaksanakan di MA Al-Amanah Baubau. MA Al-Amanah merupakan lembaga pendidikan yang terintegrasi dengan pesantren Al-Amanah. Sehingga dapat dikatakan sebagai madrasah berbasis pesantren. Pesantren AlAmanah didirikan oleh KH.Muhammad Syahruddin Saleh, MA., pada tahun 2000 dan memulai proses penerimaan siswa baru pada tahun ajaran 2001-2002.

Pendekatan penelitian yang digunakan dalam tesis ini antara lain:

a. Pendekatan statistik

Pendekatan statistik digunakan untuk mengetahui interelasi dan bentuk-bentuk interaksi yang terjadi di tengah kehidupan suatu kelompok. ${ }^{25}$

b. Pendekatan Pedagogis

Pendekatan pedagogis digunakan untuk melihat permasalahan dari perspektif pendidikan. Artinya usaha untuk merelevansikan antara teori pendidikan dengan fakta-fakta yang di temukan di lapangan.

c. Sumber data adalah populasi terbatas, yaitu siswa kelas XII MA Al-Amanah Baubau yang berjumlah 56 orang.

Teknik pengumpulan data disesuaikan dengan jenis data yang diteliti yaitu:

a. Metode Tes

Tes adalah serentetan pertanyaan atau latihan serta alat lain yang digunakan untuk mengukur keterampilan, pengetahuan intelegensi, kemampuan atau bakat yang dimiliki oleh individu atau kelompok. ${ }^{26}$

b. Studi Dokumen Hasil Tes UAMBN.

Studi dokumen hasil tes Ujian Akhir Madrasah Berstandar Nasional, bertujuan mencari data tingkat kemampuan bahasa Arab dan tingkat pemahaman ayatayat al-Qur'an siswa kelas XII MA Al-Amanah Baubau.

Instrumen yang digunakan berdasarkan tes berupa soal ujian akhir madrasah berstandar nasional yang dilakukan dengan tes tertulis sebanyak 30 butir soal, baik bahasa Arab maupun al-Qur'an. Untuk mendapatkan data interval dan diolah dengan teknik statistik.

Data bersumber dari jawaban hasil ujian akhir madrasah berstandar nasional siswa kelas XII MA Al-Amanah Baubau. Instrumen data berbentuk tes (soal) yang telah diuji validasi dan reliabilitasnya dari Kementerian Agama Republik Indonesia. Dengan demikian data ini valid dan reliabel sesuai dengan ketentuan penelitian.

Pengolahan data secara umum dilaksanakan melalui tahapan memeriksa (editing), proses identitas (coding) dan proses pembeberan (tabulating). ${ }^{27}$ Melalui tahapan tersebut, maka pengolahan data diuraikan sebagai berikut:

${ }^{25}$ Dadang Kahmad, Sosiologi Agama, (Bandung: Rosda Karya, 2000), h. 90.

${ }^{26}$ Suharsimi Arikunto, Dasar-dasar Evaluasi Pendidikan, (Jakarta: PT Bumi Aksara, 2009), h. 32 
a. Memeriksa data (editing)

Proses editing dalam penelitian ini dimulai dengan memberi identitas pada instrumen penelitian yang telah terjawab. Kemudian diperiksa satu per satu lembaran instrumen pengumpulan data, dan diperiksa juga poin-poin serta jawaban yang tersedia dalam lembaran jawaban instrumen tes (soal) UAMBN. Proses editing dilakukan sendiri tanpa ada bantuan dari peneliti lain, sambil memeriksa dan mengecek secara teliti instrumen penelitan yang dijadikan sebagai sumber data penelitian. bila terdapat kejanggalan, maka diberi identitas pada instrumen dan poin yang janggal tersebut dalam bentuk silang.

b. Pengkodean (coding)

Setelah tahapan editing dilakukan, kegiatan selanjutnya adalah mengklasifikasi data-data tersebut melalui tahapan koding. Maksudnya data yang telah diedit diberi identitas, sehingga memiliki makna tertentu pada saat dianalisis. $^{28}$ Pengkodean dalam penelitian ini menggunakan pengkodean frekuensi, karena data memiliki bobot atau frekuensi tertentu lambang. Artinya masing-masing identitas dalam instrumen penelitian memiliki kapasitas yang berbeda saat menentukan jawaban ujuan akhir madrasah berstandar nasional.

c. Porse pembeberan (tabulating)

Prose pembeberan (tabulating) dalam penelitian ini dilakukan dengan cara data dimasukan ke dalam tabel-tabel tertentu dan angka-angka diatur dan dihitung. Data tingkat kemampuan bahasa Arab dan tingkat pemahaman ayatayat al-Qur'an siswa kelas XII MA Al-Amanah Baubau dalam bentuk angkaangka.

\section{Teknik Analisis data}

Teknik analisis data menggunakan statistik deskriptif, yaitu statistik yang digunakan untuk menganalisis data dengan cara mendeskripsikan atau menggambarkan data yang telah terkumpul tanpa bermaksud membuat kesimpulan yang berlaku secara umum atau general. ${ }^{29}$

Pencarian hubungan antara variabel penelitian melalui analisis korelasi, hubungan antara tingkat kemampuan bahasa Arab dengan tingkat pemahaman ayat-ayat al-Qur'an siswa kelas XII MA Al-Amanah Baubau.

${ }^{27}$ H.M. Burhan Bungin, Metodologi Penelitian Kuantitatif: Komunikasi, Ekonomi dan Kebijakan Publik serta Ilmu-Ilmu Sosial Lainnya, Edisi ke-2, (Cet. VIII; Jakarta: Kencana, 2014), h. 174.

${ }^{28}$ H.M. Burhan Bungin, Metodologi Penelitian Kuantitatif: Komunikasi, Ekonomi dan Kebijakan Publik serta Ilmu-Ilmu Sosial Lainnya, h. 176.

${ }^{29}$ Sugiyono, Metode Penelitian Kuantitatif, Kualitatif, Dan R\&D, (Bandung: Alfabeta, 2011), h. 147. 
Teknik analisis statistik deskriptif menggunakan statistik berupa tabel frekuensi, persentase dan nilai rata-rata untuk menganalisis data dan rumusan masalah dengan rumus:

$$
\mathbf{P}=\mathbf{F} / \mathbf{N} \times 100 \%
$$

Keterangan:

$$
\begin{array}{ll}
\mathrm{F} & =\text { Frekuensi yang sedang dicari persentasenya } \\
\mathrm{N} & =\text { Jumlah frekuensi } \\
\mathrm{P} & =\text { Angka persentase } \\
100 & =\text { Bilangan tetap. }
\end{array}
$$

Untuk memudahkan analisis korelasi, digunakan perhitungan dengan bantuan Statitistical Package For the Sosial Science (SPSS) 16.0 for windows, dengan menentukan hipotesis.

$\mathrm{H}_{\mathrm{o}}$ : Tidak terdapat korelasi positif dan signifikan antara tingkat kemampuan bahasa Arab dengan tingkat pemahaman ayat-ayat alQur'an siswa kelas XII MA Al-Amanah Baubau.

$\mathrm{H}_{\mathrm{a}}$ : Terdapat korelasi positif dan signifikan antara tingkat kemampuan bahasa arab dengan tingkat pemahaman ayat-ayat al-Qur'an siswa kelas XII MA Al-Amanah Baubau.

Pengujian hipotesis terdiri dari: korelasi product moment, koefisien determinan dan uji signifikansi, dilakukan dengan langkah-langkah:

a. Analisis kofisien korelasi product moment

Beberapa teknik statistik yang dapat digunakan pengetesan hipotesis korelasi yaitu teknik korelasi jamak dan tunggal. Teknik korelasi jamak digunakan untuk penelitian yang bertujuan mencari korelasi antara tiga atau lebih variabel sedangkan teknik korelasi tunggal digunakan pada penelitian yang bertujuan mencari korelasi antara dua variabel. Mengingat penelitian ini hanya memiliki dua variabel maka digunakan pengujian hipotesis korelasi tunggal dengan menggunakan rumus teknik koefisien korelasi product moment sebagai berikut:

$$
r_{x y}=\frac{n\left(\sum X Y\right)-\left(\sum X\right) \cdot\left(\sum Y\right)}{\sqrt{\left\{n \cdot \sum X^{2}-\left(\sum X\right)^{2}\right\} \cdot\left\{n \cdot \sum Y^{2}-\left(\sum Y\right)^{2}\right\}}}
$$

Untuk memberikan interpretasi koefisien korelasi nilai $r$ antara variabel, digunakan kriteria sebagai berikut:

$$
\begin{gathered}
0,00-0,199=\text { Antara variabel } \mathrm{X} \text { dan variabel } \mathrm{Y} \text { terdapat korelasi namun } \\
\text { sangat rendah atau sangat lemah }
\end{gathered}
$$

\footnotetext{
${ }^{30}$ Anas Sudijono, Pengantar Statistik Pendidikan (Jakarta: PT. Raja Grafindo Persada, 2005), h. 43.
} 


$$
\begin{aligned}
& 0,20-0,399=\text { Antara variabel } \mathrm{X} \text { dengan variabel } \mathrm{Y} \text { terdapat korelasi } \\
& \text { rendah atau lemah } \\
& 0,40-0,599=\text { Antara variabel } \mathrm{X} \text { dengan variabel } \mathrm{Y} \text { terdapat korelasi } \\
& \text { sedang atau cukup } \\
& 0,60-0,799=\text { Antara variabel } \mathrm{X} \text { dengan variabel } \mathrm{Y} \text { terdapat korelasi kuat } \\
& \text { atau tinggi } \\
& 0,80-1,000=\text { Antara variabel } \mathrm{X} \text { dengan variabel } \mathrm{Y} \text { terdapat korelasi sangat } \\
& \text { kuat atau sangat tinggi. }{ }^{31}
\end{aligned}
$$

b. Analisis koefisien determinan

Untuk menyatakan besar kecilnya sumbangan variabel X terhadap $\mathrm{Y}$, dapat ditentukan dengan rumus koefisien determinan sebagai berikut:

$$
\mathrm{KP}=\mathrm{r}^{2} \times 100 \%
$$

Keterangan:

$$
\begin{aligned}
& \mathrm{KP}=\text { Nilai Koefisien Determinan } \\
& \mathrm{r} \quad=\text { Nilai koefisien korelasi }
\end{aligned}
$$

c. Analisis uji signifikansi

Pengujian lanjutan adalah uji signifikansi yang berfungsi untuk mencari makna hubungan variabel X terhadap Y, maka hasil korelasi product moment diuji dengan uji signifikansi sebagai berikut:

$$
t_{\text {hitung }}=\frac{r \sqrt{n-2}}{\sqrt{1-r^{2}}}
$$

Keterangan :

$t_{\text {hitung }}=$ Nilai $\mathrm{t}$

$\mathrm{r} \quad=$ Nilai koefisien korelasi

$\mathrm{n} \quad=$ Jumlah sampel

Berdasarkan uji signifikansi dengan rumus $t_{\text {hitung, dapat diketahui apakah }}$ hipotesis diterima atau ditolak dengan taraf signifikansi 0,05 $(\mathrm{a}=5 \%)$ dan derajat kebebasan $(\mathrm{dk})=\mathrm{n}-2$ dengan kaidah sebagai berikut:

1) Jika $t_{\text {hitung }}$ lebih besar dari $t_{\text {tabel }}$ maka $h_{a}$ positif atau signifikan dan $h_{o}$ ditolak atau artinya hipotesis diterima

2) Jika $t_{\text {hitung }}$ lebih kecil dari $t_{\text {tabel }}$ maka $h_{o}$ diterima dan $h_{a}$ ditolak, artinya hipotesis ditolak.

\footnotetext{
${ }^{31}$ Riduwan dan Sunarto, Pengantar Statistika Untuk Penelitian Pendidikan, Sosial, Ekonomi Komunikasi dan Bisnis (Bandung: Alfabeta, 2007),h.81.
} 


\section{HASIL PENELITIAN DAN PEMBAHASAN}

\section{A. Hasil Penelitian}

\section{Tingkat kemampuan bahasa Arab dan tingkat pemahaman ayat-} ayat al-Qur'an siswa kelas XII MA Al-Amanah Baubau.

Berdasarkan hasil penelitian bahwa frekuensi tingkat kemampuan bahasa Arab pada kategori sangat tinggi sebanyak 2 siswa (3,57\%), selanjutnya kategori tinggi sebanyak 14 siswa (25\%), pada kategori sedang sebanyak 19 (33,93\%), selanjutnya kategori rendah sebanyak 18 siswa (32,14\%), dan adapun kategori sangat rendah sebanyak 3 siswa (5,36\%). Selanjutnya, frekuensi terbesar untuk skor tingkat pemahaman ayat-ayat Al-Quran paling banyak berada pada interval 56-63 sebanyak 18 siswa $(32,14 \%)$, kemudian disusul skor siswa pada interval 6470 yaitu sebanyak 16 siswa $(28,57 \%)$.

Berdasarkan data frekuensi tersebut, menunjukkan bahwa frekuensi tingkat pemahaman ayat-ayat al-Qur'an pada kategori sangat tinggi sebanyak 4 siswa (7,14\%), kemudian di ikuti kategori tinggi sebanyak 14 siswa (25\%), selanjutnya kategori sedang sebanyak 19 siswa (33,93\%), sedangkan kategori rendah sebanyak 16 siswa $(28,57 \%)$, dan adapun kategori sangat rendah sebanyak 3 siswa $(5,36 \%)$.

\section{Korelasi antara Tingkat Kemampuan Bahasa Arab dengan Tingkat Pemahaman Ayat-ayat Al-Qur'an Siswa Kelas XII MA Al-Amanah Baubau.}

Untuk melihat seberapa signifikan korelasi tingkat kemampuan bahasa Arab dengan tingkat pemahaman ayat-ayat al-Qur'an siswa kelas XII MA AlAmanah Baubau. Maka langkah yang perlu dilakukan adalah melakukan uji $t$ dengan hasil analisis. Harga $t_{\text {hitung }}$ tersebut selanjutnya dibandingkan dengan $t_{\text {tabel }}$. Untuk kesalahan 5\% uji dua fihak, dan dengan dk 55, maka $t_{\text {table }}=1,67$ dengan demikian $t_{\text {hitumg }}$ lebih besar dari $t_{\text {tabel }}$ atau 13,68 lebih besar dari1,67 maka dapat disimpulkan terdapat korelasi yang signifikan antara tingkat kemampuan bahasa Arab dengan tingkat pemahaman ayat-ayat al-Qur'an siswa kelas XII MA Al-Amanah Baubau, maka semakin tinggi tingkat kemampuan bahasa Arab akan semakin tinggi pula tingkat pemahaman ayat-ayat al-Quran siswa kelas XII MA Al-Amanah Baubau. Untuk melihat persentase hubungan antara tingkat kemampuan bahasa Arab dan tingkat pemahaman ayat-ayat al-Qur'an digunakan rumus determinasi (R) dimana $R=r^{2} \times 100 \%$, harga $\mathrm{r}$ yang dimaksud adalah $r_{\text {hitung }}=0,881$, maka diperoleh harga $R=77,62 \%$. Kontribusi kecenderungan emosional terhadap tingkat pemahaman ayat-ayat al-Qur'an adalah 77,62\%. Angka ini menunjukkan bahwa $77,62 \%$ dari tingkat pemahaman ayat-ayat alQuran dipengaruhi oleh tingkat kemampuan bahasa Arab sedangkan 22,38\% dipengaruhi oleh faktor lain. Berdasarkan data tingkat kemampuan bahasa Arab 
dan tingkat pemahaman ayat-ayat al-Qur'an siswa kelas XII MA Al-Amanah Baubau terdapat korelasi positif dan signifikan.

\section{B. Pembahasan}

Tingkat kemampuan bahasa Arab siswa kelas XII MA Al-Amanah Baubau, berdasarkan hasil penelitian menujukkan bahwa kemampuan siswa dengan kategori sangat tinggi sebanyak 2 siswa (3,57\%). Sedangkan yang berkemampuan tinggi sebanyak 14 siswa (25\%). Selanjutnya, siswa yang berkemampuan sedang sebanyak 19 siswa (33,93\%). Sedangkan siswa yang berkemampuan rendah sebanyak 18 siswa $(32,14 \%)$. Adapun siswa yang memiliki kemampuan sangat rendah sebanyak 3 siswa $(5,36 \%)$.

Menurut Akhmat Sudrajat bahwa setiap individu memiliki kemampuan yang berbeda-beda dalam melakukan suatu tindakan. Sehingga berdasarkan data hasil penelitian kemampuan bahasa Arab terhadap siswa kelas XII MA AlAmanah Baubau sesuai dengan teori kemampuan.

Berdasarkan teori dan pembahasan tersebut, yang menyebabkan siswa memiliki tingkat kemampuan bahasa Arab yang berbeda-beda disebabkan oleh faktor internal dan faktor eksternal.

1. Faktor internal

Yang menjadi faktor internal dalam kemampuan bahasa Arab, diantaranya yaitu umur siswa, kondisi siswa, kesehatan siswa, dan intelijensi siswa.

2. Faktor eksternal

Yang menjadi faktor eksternal dalam kemampuan bahasa Arab, diantaranya yaitu status sosial dan ekonomi keluarga, hubungan keluarga, dan bahasa yang dipergunakan dalam keseharian siswa.

Berdasarkan hasil penelitian, data tingkat pemahaman ayat-ayat al-Quran siswa kelas XII MA Al-Amanah Baubau, dari tes (soal) berbentuk pilihan ganda sebanyak 30 butir soal dengan jumlah responden sebanyak 56 siswa. maka hasil diperoleh skor minimum $=45$ dan nilai maksimum $=90$, dengan nilai rata-rata (mean) variabel $Y=64,45$

Setelah diketahui mean, untuk melakukan penafsiran nilai mean yang telah didapat, peneliti membuat interval kategori. Guna menentukan jumlah kelas interval dihitung dengan rumus Sturges yaitu $1+3,3 \log n$, dimana $n$ adalah subyek penelitian, sehingga dapat diperoleh $1+3,3 \log 56=6,82$ dibulatkan menjadi 7. Rentang data sebesar 90-40 $=50$. Dengan diketahui rentang data maka dapat diperoleh panjang kelas interval masing-masing kelompok yaitu 50:7 = 7,143 dibulatkan menjadi 8 .

Hasil data diatas, menunjukkan frekuensi terbesar untuk skor tingkat pemahaman ayat-ayat Al-Quran berada pada interval 56-63 sebanyak 18 Siswa, dan interval 64-70 sebanyak 16 siswa. Selanjutnya pengkategorian tingkat 
pemahaman ayat-ayat al-Qur'an digolongkan kedalam 5 (lima) kategori yaitu sangat baik, baik, cukup, rendah dan sangat rendah.

Variabel ditentukan setelah nilai (skor) tertinggi dan nilai (skor) terendah diketahui selanjutnya rata-rata ideal (Mi) adalah 65 dan Standar Deviasi Ideal (SDi) adalah 8,33. Berdasarkan perhitungan tersebut dapat dikategorikan dalam 5 (lima) kategori sesuai dengan tabel 4.6 menunjukkan bahwa frekuensi tingkat pemahaman ayat-ayat al-Qur'an, pada kategori sangat baik sebanyak 4 siswa, sedangkan kategori baik sebanyak 14 siswa, selanjutnya kategori sedang sebanyak 19 siswa, sedangkan kategori rendah sebanyak 16 siswa, dan kategori sangat rendah sebanyak 3 siswa.

Bloom mengatakan pemahaman diartikan sebagai kemampuan untuk menyerap arti dari materi atau bacaan yang dipelajari. Jadi, seberapa besar siswa mampu menerima, menyerap pelajaran yang diberikan oleh guru kepada siswa. Dari teori tersebut lebih menekankan siswa terhadap materi pelajaran dalam menerima, menyerap pelajaran yang diberikan oleh guru.

Berdasarkan hasil presentase tingkat pemahaman ayat-ayat al-Qur'an siswa kelas XII MA Al-Amanah Baubau, yang mendapatkan persentase terbanyak pada kategori sedang sebanyak 19 siswa dari jumlah 56 siswa, sedangkan siswa yang memiliki tingkat pemahaman ayat-ayat al-Qur'an dengan kategori rendah sebanyak 16 siswa dari jumlah 56 siswa. Hal ini menunjukkan bahwa siswa kelas XII MA Al-Amanah dalam menerima/menyerap mata pelajaran al-Qur'an sangat positif dan signifikan.

Berdasarkan hasil data tersebut, pemahaman ayat-ayat Al-Quran siswa kelas XII MA Al-Amanah Baubau, menunjukkan pemahaman yang cukup dalam menerjemahkan, menafsirkan, dan mengekstrapolasi ayat-ayat al-Qur'an. Ini menunjukkan bahwa kemampuan siswa dalam memahami ayat-ayat al-Qur'an perlu ditingkatkan serta membutuhkan perhatian khusus dari pihak guru dan penyelenggara pendidikan lainnya dikarenakan MA Al-Amanah Baubau merupakan madrasah berbasis pesantren.

Berdasarkan teori dan pembahasan diatas, tingkat pemahaman ayat-ayat al-Qur'an siswa kelas XII MA Al-Amanah Baubau berbeda-beda disebabkan oleh faktor internal dan faktor eksternal.

a. Faktor internal

Yang menjadi faktor internal dalam pemahaman ayat-ayat al-Qur'an diantaranya, yaitu bakat/kecerdasan siswa, minat siswa, dan intelijensi siswa.

b. Faktor eksternal

Yang menjadi faktor eksternal dalam pemahaman ayat-ayat al-Qur'an diantaranya, yaitu sarana dan prasarana yang kurang memadai, penggunan metode pembelajaran oleh guru, dan pemanfaatan teknologi sebagai media pembelajaran. 
Korelasi antara tingkat kemampuan bahasa Arab dengan tingkat pemahaman ayat-ayat al-Qur'an siswa kelas XII MA Al-Amanah Baubau, memiliki hubungan dan memiliki keterkaitan antara tingkat kemampuan bahasa Arab dan tingkat pemahaman ayat-ayat al-Qur'an. Untuk melihat seberapa signifikan korelasi tingkat kemampuan bahasa Arab dengan tingkat pemahaman ayat-ayat al-Qur'an siswa kelas XII MA Al-Amanah Baubau sesuai dengan hasil analisis $\mathrm{t}_{\text {hitung }}$ sebesar 13,68.

Data menunjukkan terdapat korelasi yang signifikan antara tingkat kemampuan bahasa Arab dengan tingkat pemahaman ayat-ayat al-Qur'an siswa kelas XII MA Al-Amanah Baubau. Sehingga semakin tinggi tingkat kemampuan bahasa Arab maka semakin tinggi pula tingkat pemahaman ayat-ayat al-Quran siswa kelas XII MA Al-Amanah Baubau. Kontribusi kecenderungan emosional terhadap tingkat pemahaman ayat-ayat al Qur'an menunjukkan bahwa tingkat pemahaman ayat-ayat al-Quran lebih besar dipengaruhi oleh tingkat kemampuan bahasa Arab siswa kelas XII MA Al-Amanah Baubau.

Korelasi positif antara tingkat kemampuan bahasa Arab dengan tingkat pemahaman ayat-ayat al-Qur'an siswa kelas XII MA Al-Amanah Baubau adalah:

a. Untuk memahami ayat-ayat al-Qur'an, siswa dituntut memiliki kemampuan menerjemahkan, menafsirkan, dan mengekstrapolasi sehingga siswa membutuhkan/memiliki kemampuan bahasa Arab.

b. Bagi siswa yang memiliki kemampuan bahasa Arab yang baik, maka siswa tersebut dapat memahami ayat-ayat al-Qur'an secara biak. Sedangkan siswa yang memiliki kemampuan bahasa Arab yang tidak baik/rendah, maka kemampuan siswa dalam memahami ayat-ayat al-Qur'an tidak baik/rendah pula.

c. Mata pelajaran bahasa Arab dan mata pelajaran al-Qur'an sama-sama memiliki materi/bahan ajar yang berbahasa Arab, sehingga membutuhkan keahlian yang sama yaitu menerjemahkan/mengartikan ke bahasa Indonesia.

\section{PENUTUP}

\section{A. Kesimpulan}

Berdasarkan hasil penelitian dan pembahasan tersebut, dapat disimpulkan bahwa:

1. Tingkat kemampuan bahasa Arab dan tingkat pemahaman ayat-ayat al-Qur'an siswa kelas XII MA Al-Amanah Baubau sangat bervariasi hal ini ditunjukkan dengan data mean (Mi) atau tingkat rata-rata pada masing-masing variabel. Pada data mean (Mi) rata-rata tingkat kemampuan bahasa Arab kategori sangat tinggi sebanyak 2 siswa (3,57\%), kategori tinggi sebanyak 14 Siswa (25\%), kategori sedang sebanyak 19 (33,93\%), kategori rendah sebanyak 18 siswa $(32,14 \%)$, dan kategori sangat rendah sebanyak 3 siswa $(5,36 \%)$. Sementara tingkat pemahaman ayat-ayat al-Qur'an pada kategori sangat tinggi 
sebanyak 4 siswa (7,14\%), kategori tinggi sebanyak 14 siswa (25\%), kategori sedang sebanyak 19 siswa (33,93\%), kategori rendah sebanyak 16 siswa $(28,57 \%)$, dan kategori sangat rendah sebanyak 3 siswa $(5,36 \%)$.

2. Korelasi antara tingkat kemampuan bahasa Arab dengan tingkat pemahaman ayat-ayat al-Qur'an siswa kelas XII MA Al-Amanah Baubau berdasarkan analisis kuantitatif korelatif ditunjukan dengan nilai koefisien korelasi sebesar 0,881 berada dalam interval 0,80-1,000 sehingga dapat diinterpretasikan bahwa antara tingkat kemampuan bahasa Arab dengan tingkat pemahaman ayat-ayat al-Qur'an terdapat korelasi yang sangat tinggi. Sedangkan berdasarkan pengujian signifikansi dengan uji $t_{\text {hitung }}$ dengan $\mathrm{N}=56$ sebesar 13,68 , hasil $t_{\text {hitung }}$ tersebut di bandingkan dengan $t_{\text {tabel }}$ dengan $\mathrm{dk}=55$ pada taraf signifikansi $5 \%$ diperoleh hasil $t_{\text {table }}=1,67$, $\left(t_{\text {hitumg }}\right.$ lebih besar dari $t_{\text {tabel }}$ atau 13,68 lebih besar dari 1,67 ), maka

korelasi antara tingkat kemampuan bahasa Arab dengan tingkat pemahaman ayat-ayat al-Qur'an adalah signifikan. Dengan demikian terdapat hubungan yang positif dan signifikan antara tingkat kemampuan bahasa Arab dengan tingkat pemahaman ayat-ayat al-Qur'an siswa kelas XII MA Al-Amanah Baubau. Sehingga hipotesis dalam penelitian ini diterima, atau dengan kata lain tinggi rendahnya tingkat kemampuan bahasa Arab siswa kelas XII MA Al-Amanah Baubau sangat berkaitan dengan tingkat pemahaman ayat-ayat alQur'an.

\section{B. Implikasi Penelitian}

1. Penelitian ini dapat memberi sumbangsih pemikiran dan pengetahuan bagi siswa (peserta didik) dan guru (pendidik) agar lebih giat menguasai dan memahami landasan epistemologi keilmuan terkait dengan pembelajaran bahasa Arab dan al-Qur'an. Karena pembelajaran bahasa Arab di MA AlAmanah Baubau merupakan keharusan yang tidak boleh ditinggalkan. Selain itu juga, guru memberikan motivasi kepada siswa untuk selalu berusaha meningkatkan prestasi belajarnya dengan sungguh-sungguh.

2. Penelitian ini diharapkan menjadi referensi atau rujukan yang relevan bagi kaum akademisi, lembaga atau institusi penelitian lainnya dalam melakukan kajian dan penelitian yang mendalam terkait dengan tingkat kemampuan bahasa Arab dan tingkat pemahaman ayat-ayat al-Qur'an dengan pendekatan expost facto di Madrsah Aliyah Al-Amanah Baubau. 


\section{DAFTAR PUSTAKA}

Abu Bakar, Muhammad. Ilmu Nahwu Teori Mudah Untuk Mempelajari Bahasa Arab, Surabaya: Karya Abditama, 1996.

Ahmadi, Abu dan Widodo Supriyono. Psikologi Belajar (Jakarta: Rineka Cipta, 2004.

al-Khūlī, Muhammad Alî. Asalīb Tadrīs al-Lughah al-'Arabīyah, Beirut: Dar alFikr, tt.

al-Misri, Muhammad bin Mukram bin Manzur al-Afriqi. Lisan al-'Arab, Cet. I; Beirut: Dar Sadir, t.th.

al-Qattan, Syeikh Manna'. Mabahis fi 'Ulum al-Qur'an, Cet. XIII; Kairo: Maktabah Wahbah, 2004.

Arikunto, Suharsimi. Dasar-dasar Evaluasi Pendidikan, Jakarta: PT Bumi Aksara, 2009.

Arsyad, Azhar. Bahasa Arab dan Metode Pengajarannya: Beberapa Pokok Pikiran, Yogyakarta: Pustaka Pelajar, 2003.

Baidan, Nasharuddin. Metode Penafsiran al-Qur'an, Cet. I; Yogyakarta: Pustaka Siswa Offset, 2002.

Bungin, H.M. Burhan. Metodologi Penelitian Kuantitatif: Komunikasi, Ekonomi dan Kebijakan Publik serta Ilmu-Ilmu Sosial Lainnya, Edisi ke-2, Cet. VIII; Jakarta: Kencana, 2014.

Darajat, Zakiyah. Pendidikan Islam dalam Keluarga dan Sekolah, Jakarta: YPI Ruhama, 1996.

Davies, Ivor K. dan Sudarsono Sudirdjo. Pengelolaan Belajar, Jakarta: CV. Rajawali Press, 1991.

Djamarah, Syaiful Bahri dan Aswan Zaini. Strategi Belajar Mengajar, Jakarta: PT. Rineka Cipta, 1996.

Hermawan, Acep. Metodologi Pembelajaran Bahasa Arab, Cet. IV; Bandung: PT Remaja Rosdakarya, 2014.

Hoetomo. Kamus Lengkap Bahasa Indonesia, Surabaya: Mitra Pelajar, 2005.

Kahmad Dadang. Sosiologi Agama, Bandung: Rosda Karya, 2000. 
Kementerian Agama RI. Mushaf al-Qur'an dan Terjemah, Jakarta: Ummul Qura, 2017.

Majid Abdul. Belajar dan Pendidikan Agama Islam, Bandung: PT. Remaja Rosdakarya, 2014.

Poerwadarminto, W.J.S. Kamus Besar Bahasa Indonesia, Jakarta: Balai Pustaka, 1998.

Poerwardaminto, W.J.S. Kamus Umum Bahasa Indonesia, Pusat Bahasa, Depertemen Pendidikan Nasional, Edisi III, Cet.4; Jakarta: Balai Pustaka, 2011.

Riduwan dan Sunarto. Pengantar Statistika Untuk Penelitian Pendidikan, Sosial, Ekonomi Komunikasi dan Bisnis, Bandung: Alfabeta, 2007.

Silverius, Suke. Evaluasi Hasil Belajar dan Umpan Balik, Jakarta: Grasindo, 1991.

Sudijono, Anas. Pengantar Statistik Pendidikan, Jakarta: PT. Raja Grafindo Persada, 2005.

Sugiono. Metodologi Penelitian Pendidikan Pendekatan Kuantitatif, Kualitatif dan R\&D, Bandung: Alfabeta, 2011.

...... Metode Penelitian Pendidikan, Bandung: Alfabeta, 2007.

Suryabrata, Samadi. Psikologi Pendidikan, Jakarta: Rajawali, 1986.

Universitas Petra. Pengertian Kemampuan (ability). http://digilib.petra.ac.id (Akses 10 Juli 2018).

Zaidah, Jurji. Tarikhu Adab al-Lughati al-'Arabiyyah, Jakarta: Dar al-Hilal, t.th.

Zuchdi dan Darmiyati. Strategi Meningkatkan Kemampuan Membaca, Yogyakarta: UNY Press, 2007. 